Cilt-Volume: 2 | Sayl-Issue: 1 | Sayfa-Page: 108-118 | Bahar-Spring | Yıl-Year: 2017

IBAD, 2017; 2(1): 108-118

Geliş tarihi/First received: 02.02.2017 Kabul tarihi/Accepted: 03.03.2017

\title{
TÜRK SİNEMASI'NDA ÖZEL ALAN KAMUSAL ALAN KARŞITLIĞINDA ANLATIDA MEKAN ÖĞESININ KULLANIMI ${ }^{1}$
}

\author{
Dr. Berceste Gülçin ÖZDEMİR ${ }^{2}$
}

Özet

Kadınla birlikte anılan özel alan ve özel alana ait kavramlar, kadını özel alanı içinde sınırlandırmakta ve ataerkil düzenin içinde ikincilleştirmektedir, böylece düzenin sürekliliği sağlanmaya devam etmektedir. Mekan, film anlatısının unsuru olmakla birlikte özel alan/kamusal alan karşıtlığında kadın karakterlerin temsilinin tartışılabileceği alanı yaratmaktadır. Kadın karakterlerin Türk Sineması'nda mekanlarda nasıl temsil edildiği ve kadın yönetmenlerin bakış açılarından çekilen filmlerde sunulan farklılıklar temelinde bu karşıtlık üzerine tekrar düşünülmektedir. 2000'li yıllarda kadın bakış açısıyla çekilen, kadın karakterlerin anlatının merkezinde olduğu filmlerde, kadınların mekanlardaki temsili, feminist film kuramları ve feminist film pratiği bağlamında izleyiciye neler sunmaktadır sorusu, toplumsal düzende varolan yapının sorgulanmasını da ortaya koymaktadır. $\mathrm{Bu}$ minvalde, çalışmanın temelini oluşturan bu sorudan hareketle, kadın karakterlerin anlatıda mekanlardaki temsili Mieke Bal'ın mekanlar hakkındaki yorumlarından hareketle tartışılmıştır, böylece feminist film pratiği açısından, özel alan/kamusal alan karşıtlığı açısından oluşturulabilecek değişimlerin de tartışılması, hedeflenmektedir.

Anahtar Kelimeler: Türk Sineması, mekan, feminist film kuramı.

\section{THE USAGE OF THE SPACE ELEMENT IN THE TURKISH CINEMA IN THE CONTRAST OF PRIVATE SPACE - PUBLIC SPACE}

\begin{abstract}
Private space and the concepts that belong to private space which are associated with women limit women in their private spaces and subordinate them in a patriarchal order, thus the continuity of that order is provided. In this regard, the subject of the representation of women characters in cinema is becoming important. While space is an element of film narrative, it also creates the field in which the representation of women characters in the contrast of private space - public space can be discussed. This contrast is being rethought based on how the women characters are represented in spaces in the Turkish Cinema and the differences that are presented in the movies made from the perspectives of women directors. The question 'what do the representation of women in spaces present the audience in the movies in which women characters are in the center of the narrative and which were made from the perspectives of women directors in 2000s in the context of the feminist film theories and feminist film practice?' also reveals the questioning of the existing structure in the social order. Within this direction and with reference to this question that underlies this study, the representation of women characters in spaces in the narrative was discussed with reference to the comments of Mieke Bal regarding spaces, thus the changes, which can be created with regard to the feminist film practice and to the private space/public space contrast, are aimed to be discussed.

Keywords: Turkish Cinema, space, the feminist film theory.
\end{abstract}

\footnotetext{
Özgün Araştırma/Original Article

${ }^{1}$ Sempozyumda bildiri olarak sunulmuştur.

2 Sorumlu yazar/Corresponding Author: Kavram MYO, Türkiye, gulcin.ozdemir@kavram.edu.tr.
}

Copyright (C) 2016-2017 by IBAD

ISSN: 2536-4642

Doi number: http://dx.doi.org/10.21733/ibad.2100 


\section{GİRIŞ}

Kamusal alan/özel alan karşıtlığının teorisyenlerce, düşünürlerce yorumlanması ve kadının özel alanda varoluşuna dair problematiklerin hala çözüme kavuşmaması bu alanlardaki karşıtlığın nedenlerinin araştırılmasını gerektirmektedir. Klasik anlatı sineması, kamusal alan/özel alan karşıtlığını izleyiciye somut bir biçimde tekrar sunarken, kadın karakterlerin temsillerinde de toplumsal düzenin kurallarını yineleyerek izleyicilerin bu kuralları içselleştirmesini sağlamaktadır. Kadınların erkek tahakkümü altında yaşantılarını sürdürmeden özneler olarak yaşamak istemeleri en temel haklarıdır. $\mathrm{Bu}$ minvalde, çağdaş anlatı sineması kadın karakterlerin temsillerinde izleyicilere klasik anlatı sinemasının sunduğu stereotiplerden farklı stereotipler sunarak kodlanmış kuralların yapıbozuma uğratılmasında yararlı olabilecek ve kadınların öznelik'lerini hatırlatmada yardımcı olabilecektir. Çalışmada, özel alan/kamusal alan kavramlarının anlatıda mekan öğesinin tartışılmasında temel olabilecek teorisyenlerin yorumlarından bahsedilerek, film anlatısında mekan öğesi bu bağlamda özel alan/kamusal alan ayrımında tartışılacak ve Türk Sineması'nda kadın karakterlerin özel alandaki temsili incelenecektir.

\section{ÖZEL ALAN-KAMUSAL ALAN KAVRAMLARININ YORUMLANMASI}

Kamusal alan kavramı, yüzyıllardır düşünürler ve kuramcılar tarafindan üzerine düşünülen ve tartışılan kavramlardan biri olmuştur. Özel alan kavramı da kamusal alan kavramının tanımına bağlı olarak üretilmiş ve kadınlarla birlikte anılan bir kavram olarak anlamını bulmuştur. Kamu sözcüğü, Almancadan alınarak, kamusal sıfatından, 18. yüzyılda publicite ve publicity kelimeleri ile benzerlik kurularak türetilmiştir. O yüzyılda dahi çok az kullanıldığı bilinen kamu sözcüğü, Habermas’a göre, mal mübadelesinin ve toplumsal emeğin alanı olarak kurumlaşmış, burjuva toplumuna ait bir sözcüktür (Habermas 2013: 59). Mal mübadelesi ve toplumsal emeğin alanı kamu, Yunanlıların bilincinde, özel alanın karşısında bir özgürlük alemi haline gelmektedir (Habermas 2013: 60). Kamu sözcüğünün burjuva toplumuna atfedilmesi kamusal kavramının da burjuvaziye atfedileceğini öncelemektedir. Feminist teorisyen Nancy Fraser, Habermas'in sadece liberal kamusal alanı idealize etmesini değil, aynı zamanda liberal olmayan, burjuva olanları da idealize etmesine eleştirel gözle bakmıştır (Fraser 1990: 60). Kamusal alanın burjuva konseptinin anlaşılamayan ütopik bir konsept olduğu ve erkeksi bir ideolojik düşüncede meşrulaştırılmaya çalışıldığ 1 da Habermas'a getirilen eleştirilerdendir. Tüm bu eleştirel görüşlerinden yola çıkan Fraser, kamusal alan düşüncesinin ütopik bir ideal olup olmadığını sorgulamıştır (Fraser 1990: 62). Fraser, tüm sınıflarda ve etnisitelerde kadınların, toplumsal cinsiyet rollerine biçilen durumlardan dolayı, resmi ve politik katılımdan dışlandıklarını, aynı zamanda pleb erkeklere de bu bakış açısıyla yaklaşıldığını eklemiştir (Fraser 1990: 63). Dolayısıyla Fraser, kamusal alana atfedilen burjuva konseptini, pleb erkeklerin de ezildiğini dile getiren bir görüşle eleştirerek sınıfsal ayrımın yapıldığının da altını çizmiştir.

Siyaset kuramcisı Jeff Weintraub'a göre, feministler, özel alan/kamusal alan ayrımının hem sosyal yapı hem de ideoloji açısından toplumsal cinsiyetle bağlantılı olduğunu vurgulamışlardır (Weintraub 1997: 28). Feminist siyaset kuramcısı Carol Pateman'ın düşüncelerine değinen Weintraub, 'Ev/aile ilgili alanın feministler için paradigmatik bir şekilde özel olmasından dolayl, sivil toplum "kamusal" alandır." diye belirttiğini söylemiştir. Devlet ve sivil toplum 
arasındaki ayrım açısından kamusal alanın/özel alanın, tarihsel/liberal formülasyonu, toplumsal yaşamın önemli belli hakikatlerinin anlaşılmasını güçleştirmekte, liberalizmin, sivil toplumu ev/özel alandan bağımsız kavramsallaştırması sebebiyle, teorik tartışmalarda özel alanın unutulduğunu eklemektedir. Bu bağlamda, özel ve kamusal arasındaki ayrımın, erkeklerin dünyasında sivil toplum içindeki bir ayrım olarak yeniden kurulduğu belirtilmektedir (Weintraub 1997: 31). Siyaset bilimci Hannah Arendt, özel alan/kamusal alan üzerine düşünerek, tartış1labilir yorumlarda bulunmuş bir kuramcidır. Hannah Arendt'e göre ise, 'kamu alanında gözüken her şey, herkes tarafindan görülebilir ve duyulabilir' olmaktadır (Arendt 2011: 92). Bu tanımla kamusal alan, herkesin erişebileceği, sınıfsal bir ayrımın yapılmadığı alan olarak okunmaktadır. Arendt'in kamusal alan ifadesine göre, insanların birbirlerinin üzerine yıkılmasını önleyen bu alan, ruh çağırma seansında masa etrafinda toplanmış insanlar örneğinden yola çıkarak anlatılmaya çalışılmıştır. Bir hokuspokusla masanın ortadan kaybolmasına tanık olan insanlar, karşılıklı iki kişi otururlarken aralarında somut bir şey olmayan ilişkisiz bir konuma gelirler. İnsanlar arasındaki biraradalığı meydana getiren ve toplumu bağlantılandırma gücünü elinde tutan dünya, Arendt'e göre bu gücünü yitirmiștir (Arendt 2011: 96). Bu nedenle bir nesilliğine değil, ölümlü insanların da yaşam sürelerini aşacak bir kamusal mekanın varlığını istemektedir (Arendt 2011: 99). Arendt'in oluşmasını istediği kamusal mekan özgürlükçülüğü, çoğulluğu ve farklı1ıkları içinde barındırmaktadır. Onun önermesinden hareketle oluşturulacak kamusal mekanlar, feminizmlerin varyasyonları için de ortak bir önerme olabilecek yapıdadır. 'Dünyevi gerçekliği hakiki ve güvenilir bir yoldan kendini gösterebileceği yegane yer, şeylerin çevrelerinde toplananların bütün bu farklllı̆̆l içinde aynilığ gördüklerini bilecek şsekilde, kimliklerini değiş̧tirmeden bütün yönleriyle ve birçok kişi tarafindan izlenebildiği yerdir." der (Arendt 2011: 102). Arendt, cinsiyet, ırk, din ve dil farkı gözetmeksizin insanların üzerinde yaşadıkları ve paylaşımlarını gerçekleştirdikleri ortak dünyada, farklılıklara rağmen, aynılıkları bularak ve kimliklerinden de ödün vermeyerek dünyevi gerçekliğe ulaşılmasını istemektedir. Kamusal alanlar oluşturulurken, Arendt'in fikirlerinden hareketle toplumun belleğinde yer etmiş eril olguları kırarak bu olguları yeniden yapılandırmak, kadınların dünyadaki mücadelesine katkıda bulunacaktır. Sosyolog Richard Sennett, kamusal alanın, özel alanla bağlantılı olarak var olduğunu söylemekte ve kamusal alanın bir coğrafya olduğundan bahsetmektedir. Bu coğrafyada, görsel ve sözel ilkeler de kamusal alanı hissetme araçları olmaktadır (Sennett 2013: 125). Bu bağlamda, kamusal alan ile özel alanı tamamen farklı birbirinden ayrı alanlar görmek ve yorumlamak da tartışılır olmaktadır. Çünkü Sennett'in de ifade ettiği gibi, özel alanla ilişkili olan unsurlar kamusal alanın içine sızmıştır. Özel alanın, kamusal alana göre ikincilleştirilmesi ve bu şekilde yorumlanması da doğru bir çıkarım olmamaktadır. Bu minvalde, özel alanda gerçekleştirilen eylemlerin, kamusal alanı varedebileceği ve kamusal alan düzeninin devam ettirilmesinde önemli bir işlevselliğe sahip oluşu göz önünde bulundurulmalıdır. Tüm bu tartışmalar ve düşüncelerde, özel alan/kamusal alan karşıtllğıında meydana gelen ayrımların temelinde yatan nedenler, toplumsal cinsiyet rollerine atfedilen kodlarla birlikte, toplumsal düzende yüzyıllardır süregelen erkek tahakkümünün sürekliliğidir. $\mathrm{Bu}$ süreklilik ancak radikal hareketlenmeler ve söylemlerle yıkılabilecektir. Sinemanın önemi de bu noktada ortaya çıkmaktadır.

Peki sinemada, kadın karakterler, özel alan/kamusal ayrımında nasıl temsil edilmektedirler? Mekanların film anlatısında kullanımı, işlevleri, karakterle ilişkileri ve karakterlerin mekanlardaki temsili, izleyicinin film izleme deneyiminde neler sunmaktadır gibi soruların cevapları, film anlatısında mekan kavramının klasik anlatı sineması ve çağdaş anlatı sinemasındaki farklı temsillerle tartışılmaktadır. Claire Johnston,'Feminist film kuramı ve pratiği içinde daha somut olarak ideolojik mücadele verme anlayışını kuramlaştırmanın olası olduğu anda, artık sahnedeki 
yerini alıyoruz." (Nelmes 2015: 17) demiş ve ideolojik olarak mücadelede bulunmanın da bir o kadar feminist film pratiği için önem arz ettiğini belirtmiştir. Sanat yapıtlarının mevcut ekonomik ilişkiler sisteminin ürünleri olduğunu ve filmlerin de burjuva ideolojisinin ürünleri olarak ortaya çıktığını öne süren Johnston, kadınları özel alanlarıyla bütünleşik olarak izleyiciye sunan klasik anlatı sinemasına eleştirel gözle bakılmasını sağlamıştır (Johnston 2008: 288). Barbara O’Connor ise, bazı bağımsız filmlerin patriarkal söylemi alt üst ettiğini ve kesintiye uğrattığını belirtmiş̧ir (O’Connor 1984: 80). Dünya sinema tarihinde kadın yönetmenler tarafindan çekilen; Yentl (Barbara Streisand-1983), Vagabond (Agnes Varda-1985), The Piano (Jane Campion-1993), Iron Jawed Angels (Katja Von Garnier-2004), Where Do We Go (Nadina Labaki-2011), Elles (Małgorzata Szumowska-2013), Antonia's Line (Marleen Gorris-1997), North Country (Niki Caro-2005), Suffragette (Sarah Gavron-2015), Certain Women (Kelly Reichardt-2016), Wendy and Lucy (Kelly Reichardt-2008) gibi filmler, kadın karakterleri kamusal alanda temsil ederken, kamusal alandaki mekanlarda erkek karakterlerin desteği olmadan ayakta kalmayı başarabilmiş, özneliklerini ortaya koyabilmiş ve klasik anlatı sinemasının erkek izleyiciye sunduğu hazzı kesintiye uğratmayı başaran film örneklerini oluşturmuşlardır. Özel alan/kamusal alan karşıtlığında kadınların varoluşlarının görünürlügünü göstermek için sinemaya büyük görevler düşerken, kadın yönetmenlerin kadın bakış açısıyla çektikleri filmlerde de bu görünürlüğün izleyici tarafından içselleştirilmesi, feminist film kuramcıları açısından feminist bakış açısını içeren filmler üretilmesinde çözüm stratejisi sunabilecektir.

\section{FÍLM ANLATISINDA MEKAN ÖĞESINIIN ÖZEL ALAN/ KAMUSAL ALAN AYRIMINDA TARTIŞILMASI}

Klasik anlatı filmlerinde mekanların sunumu, çağdaş anlatı yapısına sahip filmlerden daha farklı olmaktadır. Klasik anlatı yapısına sahip filmlerde mekanlar, anlatının temel öğesi görevini görerek, çoğu zaman işlevselliği ile ön plana çıkamamaktadır. Oysaki çağdaş anlatı yapısına sahip filmlerde mekan kullanımının işlevselliği ve mekanın kendi içindeki anlamlılığı ön plandadır. Mekan, anlatının temel öğelerinden biri olarak, bazen anlatının da önüne geçebilir, bu bağlamda önemli olan, karakterle mekanın kurduğu ilişki biçimidir. Mekan anlatıda önemli bir öğe olarak izleyiciye sunulsa dahi, karakterin mekan içindeki hareketliliği ve olay örgüsünün karakterin hareketleri aracıllğıyla şekillenmesi gibi faktörler, izleyicinin film anlatısını izleme deneyiminde etkili olmaktadır.

Mieke Bal, Narratology Introduction to the Theory of Narrative (1985) adli kitabında, mekanın hikayedeki temsilinin önemine değinerek; görmenin, duymanın ve dokunmanın algısal olarak mekan temsilinin içeriğinde bulunduğunu belirtmiştir (Bal 1999: 133). Karakterin güven içinde olması ya da güvensiz hissetmesi de mekanların iç mekan ve dış mekan olarak ayrımında görülmektedir. Bal, iç mekan, sınırlamanın deneyimlendiği mekan olarak güvensizken, dış mekan, özgürlüğü temsil eder ve dolayısıyla güvenlidir, der (Bal 1999: 134). Mekan, öyküyü etkiler ve böylece öykü, mekanın sunumunun geri planına itilir. Mekan, daha öne çıkar bazen. Durağan mekan, tematize olsun olmasın sabit çerçeveyi belirtir ve bu çerçevenin içinde olaylar meydana gelir. Dinamik olarak işlev gören bir mekan ise, karakterlerin hareketine izin verir, karakterler burada yürürler, o yüzden de bir yola ihtiyaçları vardır. Büyük alanlara da ihtiyaçları vardır, burada seyahat ederler (Bal 1999: 136). İç mekanlar, özel alanları gösterdiği için kadın karakterlerin daha fazla görülebildiği mekanlar olmuştur. Dış mekanlar ise, kamusal alanlar olarak erkek karakterlerin daha çok izleyiciye sunulduğu mekanlardır. Ancak, bu genelleme klasik anlatı sineması için söylenebilinmektedir. Çağdaş anlatı sinemasında, kadın karakterlerin dış mekanlarda temsil edildiği filmler olmakla beraber, kadın karakterlerin politik temsillerinde de farklı söylemler üretilmektedir. Durağan 
mekanlar, karakterlerin hareketlerine kısıtlı olanak sağlarken, dinamik mekanlar geniş alanlarda sonsuz hareket olanağını sunmaktadırlar. Kadın karakterlerin özgürce dış mekanlarda istedikleri saatte güvenli biçimde gezebileceği, dinamik mekanlarda başlarına hiçbir şey gelmeden hareket edebilecekleri toplumsal düzen, Türkiye'de olmadığı gibi dünya konjonktüründe de çok fazla bulunmamaktadır. Dolayısıyla, izleyicilerin izlediği film anlatılarındaki karakterler ve mekanlarda, varolan konjonktürdeki gerçeklik sunulmaktadır. Ancak, burada tartışılması gereken varolan düzeni değiştirmek ve dönüştürmek adına farklı ve radikal temsillerin de sunulması gerekliliğidir. Kadın karakterlerin eşik alanlardan hayatı izlemediği, yaşamlarını dinamik mekanlarda deneyimledikleri, geniş hareket alanlarına salık verildiği ve tek başlarına varolabildikleri anlatılarla, izleyici de toplumsal düzende kadınların varlı̆̆ının kamusal alanda değerli olarak sunulduğu filmleri izleyerek düzenin değişme ihtimallerini görebileceklerdir. Bu bağlamda önemli olan noktalardan biri de kadınların görünürlükleri meselesi olmaktadır. Görünürlüğün somut biçimde toplumsal düzen içine yer edinebilmesi açısından sinemanın mutlak katkısı kaçınılmazdır. Mamafih, klasik anlatı sineması kadınların görünürlüğü adına kadın karakterleri izleyiciye, patriarkın kuralları içindeki karakterler olarak sunmaktadır. Klasik anlatı sinemasında kamusal alanda sunulan kadın karakterler film sonunda ya cezalandırılmakta ya da fetiş nesnesine dönüştürülerek hazza hizmet edenler olarak görülmektedir. Bu bağlamda, çağdaş anlatı yapısını kullanan filmlerin feminist film pratiğine katk1 sağlayacağı düşünülmektedir. Çünkü, erkek tahakkümünün hissedilmediği filmlerin üretilmesi, klasik anlatı sinemasının kodları ile oynayarak kadınlığın varoluşuna dair olumlayıcı söylemleri izleyicinin izleyebilmesi, çağdaş anlatı yapısının kullanımıyla gerçekleşebilecektir. Çağdaş anlatı yapısına sahip filmlerde olay örgüsünün gelişimi düz bir çizgide ilerlemediği gibi, yan olay örgüleri de anlatıda bulunabilmektedir. Ancak, yan olay örgülerinin, ana olay örgüsünden tamamen bağlantısız olduğu durumlar da ortaya çıkabilmektedir. Böylece izleyici filmi izleme deneyiminde sorgulamacı bir konumda bulunmaktadır. Keza filmlerin konuları, karakterlerin temsili ve sinematografik öğelerdeki alternatif denemeler izleyicinin aşina olduğu klasik anlatı yapısından farklı temsiller sunabilmektedir. Filmlerin kapanışlarındaki muğlaklık, klasik anlatı sinemasında izleyicinin karakterle özdeşleşme mekanizmasının sinematik dille yapıbozuma uğratılması, karakterlerin iç ve dış dünyalarındaki çatışmaların metaforlarla izleyiciye sunulması, film izleme deneyiminde izleyicinin filmi izlediğinin hatırlatılması, anlatının geçişsizliği, nedensel motivasyonun düz çizgide ilerlemeyerek eğilimli hale gelmesi ve izleyicinin olay örgüsünü sorgulamasını sağlaması gibi özellikler, çağdaş anlatı yapısına ait özelliklerdir. Mekan kullanımı da çağdaş anlatı sinemasında, salt film anlatısının mekanları olarak kullanılmak yerine bazen tek başına dahi anlatı içerisinde anlam taşıyabilmektedir. Mekanın karakterle ve öykü ile kurduğu ilişkide, anlatının merkezinde kullanılan mekanlar, karakterlerin temsillerinin tartışılmasında da önem taşımaktadır. Bu minvalde, feminist film kuramları, çağdaş anlatı yapısı niteliği taşıyan film janrlarının kadın karakterlerin temsilinde radikal söylemler üretebileceğini düşünmektedir. Feminist film kuramları yanında feminist film pratiği için de üretilen filmlerde kadın karakter temsillerinin tartışılması gerekmektedir. Kadın karakterlerin anlatı merkezine yerleştirilerek, kadınların konu edilmesinin öneminin yanında kamusal alanlarda nasıl temsil edildiklerinin de önemi burada yatmaktadır.

\section{TÜRK SINEMASI'NDA KADIN KARAKTERLERIN ÖZEL ALANDA TEMSILI}

Türk Sineması'nda kadın karakterlerin özel alanda temsili, toplumsal düzenin kodlarıyla paralellik oluşturacak biçimde izleyiciye sunulmuştur. Kadın karakterler evinin vefakar annesi, evin düzenleyicisi, çocuklarının anası, eşinin namusu olarak 
sunulurken, kamusal alanda sunulan kadınlar da özel alanlarından koparılmadan özel alanlarıyla ilgili konular içinde sunulmuş ya da güçlü kadın stereotipi ile film kapanışında cezalandırılmışlardır. Klasik anlatı sinemasında kadın karakterlerin arzu nesnesi, fetişleştirilmiş nesne haline getirilişi ve erkek izleyici hazzına hizmet eder biçimde sunumu dünya sinema tarihi boyunca tekrarlanmıştır. $\mathrm{Bu}$ düzeni kıran çağdaş anlatı yapısının kullanıldığı filmler olmuştur. Kadının kadın olarak sunulduğu, kadına dair gerçekliklerin radikal biçimde izleyiciyle buluşması sonucu izleyici de kadınlığa dair olanı görmeye başlamıştır. Kadınların dertlerinin, sevinçlerinin, deneyimlerinin kadın karakterler tarafından temsil edilişinde, ideolojik ve estetik olarak film anlatısı söyleminde yer alışında, toplumsal düzenin kurallarından izlere rastlayan izleyiciler, toplumsal düzene eleştirel bakan yönetmenler sayesinde de düzeni tekrar düşünmeye başlamışlardır. Günümüzde hala kadınların ikincilleştirildiği filmlerin söylemleriyle ataerkil kurallar pekiştirilmektedir. Ancak, çağdaş anlatı yapısını kullanan filmlerde alışıldık stereotiplerden farklı kadın karakterleri izleyici görebilmektedir. Çağdaş anlatının getirdiği farklılıklarla izleyici, çeşitli kadın stereotiplerinin varolduğunu görebilmekte, böylece ataerkil düzeni sorgulayabilmektedir.

Türk Sineması'nın başlangıç yıllarında, Pençe (Sedat Simavi-1918), Mürebbiye (Ahmet Fehim-1919) gibi filmlerde kadın karakterlerin temsil ediliş biçimi klasik anlatı yapısında alışılagelen kadın stereotiplerinin dışına çıkabilmiştir. Pençe filminin tamamını izleme olanağımız yoktur, ancak kadın cinselliğinden ilk defa bu kadar açık biçimde bahseden bir film olduğu hakkında bilgiler mevcuttur. Filmde, cinselliğini özgürce yaşantılayabilen bir kadın karakterin hayatının anlatıldığı Giovanni Scognamillo'nun aktarımlarına göre söylenmektedir. Scognamillo, Pençe'nin kayıp bir film olduğundan bahseder ve töresel bir sonu olmasına rağmen, o yıllar için olay ve kişileriyle cüretli olan bu konunun perdeye nasıl aktarıldığ hakkında bilgi sahibi olunmamasını ifade etmektedir (Scognamillo 1990: 27). Mürebbiye filmi ise, Türkiye'de sansüre uğramış bir ilk film olmanın yanı sıra konusuyla da kadın karakter temsilinde farklılık sunmaktadır. Fransa'dan Türkiye'ye gelen bir genç kadının yaptığı olayları konu alan film, kadın karakteri, cinselliğini özgürce yaşayan bir karakter olarak göstermektedir. Agah Özgüç, Mürebbiye'nin kadın kahraman üzerine kurulu ilk Türk filmi olduğunu söylemektedir (Özgüç 2000: 16). Cinselliği ve duygusal yoğunluğu hem cinsiyle yaşayan kadın karakterler de Türk Sineması tarihinde sunulmuştur. Ikki Gemi Yan Yana (Atıf Yılmaz-1963), iki kadın arasındaki duygusal bir yoğunluğa işaret ederken, Düş Gezginleri (Atıf Yılmaz-1992) filminde de kadın karakterler arasındaki üstü kapalı duygusal heyecanlar izleyiciye verilmektedir. Böylece klasik anlatı sinemasında sunulan kadın karakterlerden farklı kadın karakterlerin de olabileceğini izleyici görmüş olmaktadır. 1940'l1 1950'li yıllarda, Amerikan sinemasından kaynaklanan yıldızcılık yönteminin de etkisiyle, gözü yaşlı saf genç kızlarla, erkek jönleri ayartmak için cinselliğini kullanan kötü kadınlar, izleyici ile buluşmuştur (Demirhan, Scognamillo 2002: 28). 1950'li yıllarda, kadın temsillerinde; harem görüntüleri, banyo sahneleri gibi görüntülerin ilk kez görüldüğü iddia edilse de, Tiyatrocular Dönemi (1922- 1939) olarak adlandırılan dönemde de; Karım Beni Aldatırsa (Muhsin Ertuğrul-1933), Binnaz (Ahmet Fehim-1919) gibi filmlerde de bu tarz sahnelere rastlanabileceği söylenmektedir (Duyan 2013: 335). Metin Demirhan, Giovanni Scognamillo’ya göre, 50'li 60'll yıllarda pek hareketlenmeyen saf genç kız tipi, 70'lerde cinsel yaşamını benimseyerek ve kadınlığını kabul ederek daha güncel ve daha çağdaşlaşmaya başlamıştır (Demirhan, Scognamillo 2002: 36). Bir yandan melodram filmler bir yandan Amerikan filmlerinin etkisinde kalan Türk sineması 60'lı 70'li yıllar arasında konu açısından değişken bir çizgi izlemiştir. Hasan Akbulut, 1960-1975 yılları arasında, yerli melodramlardaki kadın temsillerinin toplumsal cinsiyet kalıplarını yeniden ürettiğini belirtmektedir. Akbulut'a göre, kadını ve kadınlı rollerini erkeğin gereksinimlerine göre 
kodlayan bu süreç, kadını; "uysal, "güçsüz" ve "çaresiz" olarak tanımlamaktadır, ancak bu tanımlamalar gerçek kadınların göstergesi olmamakla birlikte, erkek bilinçaltını temsil eden bir gösterge işlevi yüklenmektedir (Akbulut 2008: 356). 1970'li yıllar Türk Sineması'nda bir yandan da seks furyasının yaşandığı yıllar olmuştur. Kadına uygulanan klasik ayrımın (saf genç kız, kötü kadın) Yeşilçam kurallarını sarstığı ve Türk Sineması'nı da çöküşe doğru ilerlettiği ifade edilmektedir (Demirhan, Scognamillo 2002: 12). Seks içerikli filmler üretilirken, izleyici portreleri de değişmiş̧ir. Seks içerikli filmlerin ticari kaygılar güdülerek yapılması, farklı filmlerin negatiflerinden yararlanarak sahne çoğaltma işlemine gidilmesi ve bu konulardan başka temalarda olan filmlerin sayıca az olması gibi nedenlerle bu dönemde sinematik dilde de gelişme bir anlamda engellenmiş olmaktadır. 1980'li yıllara kadar, Türk Sineması'nın kadın temsillerini; iyi kadın, kötü kadın olmak üzere ikiye ayırmasını Şükran Esen, detaylı şekilde şöyle açıklamaktadır: ' Kadınlar ya namuslu, evinin kadını, çocuklarının anası, cinselliği olmayan, sevgi dolu, sürekli bağışlayan, ezildiğini hissetse de gözyaşlarını içine akttı evin mutluluğunu bozmayan kadınlardır. Ya da cinselliğinden başka bir şeyi olmayan, kötü, mutlu yuvalara düşman, erkekleri kötü yollara sürükleyen vamp kadınlar. Bu iki ana tipin dışında, filmlerde ortalıkta gezinen, olayın aklşı içinde perdede görünen ama varlıkları bile farkedilmeyen kadınlarla dolu Türk Sineması.',

(Esen 2000: 29). Esen'in çıkarımından hareketle kadın karakterlerin filmlerde temsili incelendiğinde, temsil edildikleri mekanların da, temsil ediliş biçimleri ile paralellik gösterdiği görülmektedir. Özel alanından kopamayan, kamusal alanın dışladığı kadın karakterlerin temsili Türk Sineması'nda bu yıllarda da devam etmiştir. Ancak, klasik anlatı sinemasının izleyiciye sunduğu kadın karakterlerden farklı kadın stereotiplerinin de sunulduğu filmler izleyiciyle buluşmuştur. Klasik anlatı yapısının kullanıldığı filmlerde kadın yönetmenlerin bakış açılarından kadınların izleyiciye sunulduğu filmler de kadın karakterlerin temsili açısından önem taşımaktadır. Fetay Soykan'ın kadın yönetmenlerin kadına bakışını konu alan filmler olarak gruplandırdığı; Bilge Olgaç'ın, Açlık (1974), Kaşık Düşmanı (1984), Gülüşan (1986), Türkan Şoray'ın, Dönüş (1972), Bodrum Hakimi (1975), Yılanı Öldürseler (1981), Nisan Akman'ın, Beyaz Bisiklet (1987), Bir Kirık Bebek (1987), Dünden Sonra Yarından Önce (1988), Mahinur Ergun'un Medcezir Manzaralarl (1989) filmleri klasik anlatı yapısını kullanan filmler olsa dahi kadınları anlatan filmler olmuşlardır (Soykan 1993: 147). 1990'larda Türk Sineması adına birçok gelişme olması ile birlikte sinematik dilin de gelişimi sağlanmıştır. Ertan Tunç'un 1990'lı yıllardaki Türk Sineması'nın gelişimi ile ilgili düşünceleri, Türk Sineması'nın gelişimindeki ekonomik temelin önemini ortaya koymaktadır: '1990'll yıllardan itibaren büyük Amerikan şirketlerinin Türkiye'deki dă̆ıtım ă̆larının kontrolünü ele geçirmiş olmasl, Türk Sineması'nın Eurimages, yerli ve yabancı festivallerin ödülleri, reklam ve sponsorluk anlaşmaları, özel televizyonlar gibi yeni finansal kaynaklarla tanışması, reklam ve medya sektörü sayesinde teknik kalitesini had safhaya çıkartabilmiş olması yeni bir ayrımın varlığını zorunlu kılmaktadır."' (Coşkun 2015: 2). Tüm bu gelişmelerle genç, farklı, bağımsız yönetmenler eserler üretmeye başlamıştır. Ulusal ve uluslararası film festivallerinde, Türk Sineması adına yeni sinematik dillerle kendini ifade etmeye çalışan yönetmenlerin kadın temsillerinde de önceki yıllardan farklı bakış açısını barındıran filmler üretilmiştir. Özellikle sanat sinemasının gelişimi ile birlikte anlatıda mekanların sunumunda da farklılaşmalar olmuştur. Aidiyetsizlik, bireysellik ve yalnızlık gibi temaların öne çıktığı filmler yapılmaya başlanmıştır. İzleyicinin daha fazla sorgulamalarda bulunduğu filmlerle kadının temsili de sorgulanmaya başlanmıştır. Türsel çeşitlilikle birlikte başka noktalardan kadınlara bakabilmenin varyasyonları artmış ve kadınları anlatmanın biçimleri çoğalmışıı. Ancak, kadın karakterler özel alan dışında çokça temsil edilmiştir de denilememektedir. Kadına sinemada atfedilen rollerle bağlantılı olarak özel alanlarında hayatlarını idame ettirişleri 2000'li yıllar 
Türk Sineması'nda da devam etmektedir. Her ne kadar klasik anlatı yapısının dışına çıkan filmlerle, kadın karakterlerin rolleri, alışılmış kodların dışına çıkıyor olsa da, özel alanın kadın karakterlerle olan ilişkisi izleyiciye sunulmuştur. Çağdaş anlatı yapısını içeren anlatımlar kullanılsa dahi kadın karakterlerin belli stereotipler altında sunulması ve özel alanın kadınla ilişkilendirilmesi gibi konular feminist film pratiğinin gelişimi için üzerinde düşünülmesi gereken konulardır. Toplumsal düzenin kadına yüklediği kodlar, sinemada da varlığını devam ettirmektedir. Özne olmaktan yoksun kılınan, edilgenliğiyle öne çıkan kadın karakterler kendi alanlarını dahi seçebilme şansına sahip değillerdir. Özel alanlarında kısılıp kalan kadın karakterlerin bu alanlarda dahi özgürlüklerini yaşayamamaları sorunu, görünen açık bir gerçekliktir. Ev içerisindeki sınır çizgileri içinde yaşamaya çalışan ve alıştııılan kadınlar, evde de özgür olamazlar ise nasıl varolacaklardır. Sinematografinin gelişimi üzerine düşünmenin yanı sıra, yönetmenlerin kadın karakterleri temsil biçimini de düşünmek önem arz etmektedir. Çünkü kadın ve erkek yönetmenlerin karakterleri temsilinde farkl1liklar bulunmaktadır. Kadın yönetmenin kadın karakter öykülerini anlatırken karakterle kurduğu empati ve kadın olmasından kaynaklanan kadın karakteri sunarken hissettiği istemsiz bakış açısı, kadın karakterlerin temsilinde erkek yönetmenlerin temsiline göre farklılıklar yaratmaktadır. Bu bağlamda, feminist film kuramcılarının da kadın yönetmenlerden feminist film pratiği adına beklentileri vardır. Anneke Smelik, özgürleştirici kadın sinemasının nasıl olması gerektiğinin tahmin edilebilir olduğundan bahseder ve şöyle der: 'Kadın yönetmenler beyazperdede 'gerçek' kadınların 'gerçek' hayatlarını göstererek, kadınlığa dair her yerde karşımıza çıkan ve kültürel açıdan egemen konumdaki fantezi büyüsünü bozabilirler. Örneğin bir Greta Garbo'nun, bir Marlene Dietrich 'in ya da bir Marilyn Monroe'nun parlttssina karşı kadın yönetmenler, normal yani parıltısız kadının gündelik hayatını filme çekmelidirler." (Smelik 2008: 3). Bu bağlamda, kadın karakterlerin gündelik yaşantılarının izleyici sunumunda nasıl sunulduğu konusu önem teşkil etmektedir ki feminist kuramcıların da tartıştığ kadın karakterlerin temsil ediliş şeklidir.

2000'li yıllarda ortaya çıkan yeni kuşak yönetmenlerle, farklı sinematik dillerin denemelerle, feminist film pratiği açısından katkı sağlayan filmlerle kadın karakterlerin film anlatılarındaki görünürlüğü kadın yönetmenler tarafından arttırılmıştır. Nefesim Kesilene Kadar (Emine Emel Balc1-2015), Şimdiki Zaman (Belmin Söylemez-2012) gibi filmler kamusal alanda varolmaya çalışan kadın karakter stereotipinin örneklerini izleyiciye sunmuşlardır. $\mathrm{Bu}$ film anlatılarında mekanların tasarlanmasında, mekanın işlevselliğinin yanında karakterlerin iç dünyalarıyla da bağlantılar kurulmuştur. $\mathrm{Bu}$ nedenle, hem kadın karakterlerin temsilinde hem de mekanın öykü ve karakterle olan ilişkisinde klasik anlatı kodlarının yeniden düşünülmesini sağlamışlardır. Senaryo ve karakter analizinin yanı sıra, toplumsal düzenin kodları da düşünülerek film anlatısında mekan tasarım gerçekleştirilmelidir. Çünkü topluma dair olan her şey bir şekilde film anlatısında kullanılan mekanların içinde de sızıntısını gösterecektir. Beatriz Colomina, ünlü mimar Adolf Loos'ın ev ile ilgili söylediklerinden hareketle, iç mekan ve dış mekanla ilgili Loos'un fikirleriyle ilgili yorumda bulunmuştur. Loos'a göre, '’ $E v$, dışarıya bir şey söylemek zorunda değildir; tersine, bütün zenginliği içeride apaçık olmalıdır.' Colomina, Loos'un içerisi ve dışarısı arasındaki ayrımını yorumlamıştır ve dışarının; mübadele, para ve maskelerin alanı olduğundan, içerinin ise; yabancılaştırılamayan, mübadele edilemeyen, tarifsiz olanın alanı olduğunu belirterek ve bu iki ayrımın nedeninin toplumsal cinsiyetten kaynaklandığını da eklemiştir. Colomina, Loos'un, evin dışını bir smokine, erkek maskesine benzettiğini söyler ve dikişsiz bir cephenin koruduğu bütünleşmiş eril benlikle paralellik taşıdığını belirtmektedir. İçerisini ise, cinselliğin ve üremenin sahnesi olarak niteleyip, dış dünyada özneyi bölecek her şeyin sahnesi olarak açıklamaktadır (Colomina 2011: 273). Ivan Illıch de, bedenlerin mekanı şekillendirdiğini, mekan 
düzenlemelerinin de bedenleri şekillendirdiğini belirtmiş ve toplumsal cinsiyetin vücutları şekillendirdiğini eklemiştir. Yaşamın, mesken tutmak olduğundan bahseden Illıch, bir meskeni şekillendirmenin bütün yaşamı içerdiğini ifade etmiştir (Illıch 1996: 148-149). Bu nedenle, toplumsal cinsiyete ait kavramlar, toplumsal düzene ait yerleşmiş kalıplar, sadece bedenlerimizi değil mekanları da şekillendirirken, bireylerin özgürleşmesini kısıtlamıştır ve özel alanlarında sıkıştırılmış özne(s)neleştirilmiş bireyleri yaratmanın izi sürülmüştür (Kavram yazara aittir) Feminist mekan politikasıyla ilgili düşünürken, toplumsal düzen ve toplumsal cinsiyet kavramlarının altının bu kadar sık çizilmesinin nedeninin altında, Alison Butler'ın da söylediği gibi, tüm bu kavramların birbiriyle olan ayrılamaz ilişki biçimi yatmaktadır. Alison Butler'dan aktaran Nejat Ulusay: ''Kadın sinemasında, feminist bir mekan politikasinin, toplumsal cinsiyet teknolojileri ile yerel, ulusal ve uluslararası iktidar teknolojilerinin nasıl örtüştügünü açı̆̆a çıkarmak üzere, kadın kimliğini dinamik tarihsel durumların içine yerleştiren filmler tarafindan dile getirildiğini işaret ettiğini." söylemektedir. Ulusay, ulusla aile arasındaki somut bağın, toplumsal bir sisteme, aile yapısına işaret eden patriarki kavramı olduğunu vurgulamıştır (Ulusay 2008: 245).

\section{SONUÇ VE TARTIŞMA}

Gündelik ihtiyaçları yerine getirmek bir yana, bireyin hayallerine, düşüncelerine ve yaşamını sürdürme şekline karşı yapılan tahakkümler, kadın karakterlerin "kadın" olarak varolma durumunu yansitmamakla birlikte, patriarkın bakış açısının sürdürülmesine de aracılık etmektedir. Türk Sineması tarihinde kadın karakterlerin özel alanlarında temsilinde kadınların evlerinde dahi 'ben'" $i$ hissedememeleri, onlara yüklenen edilgen rolleri devam ettirmektedir ve izleyicilerin bakış açısının bu minvalde içselleştirilmesinin devamı da böylece sağlanmaktadır. Sinemada devam ettirilen ataerkil eylemler, toplumsal düzende kadına dair olumlamalar yapmadığı gibi, kadının ikincil konumunu da pekiştirmektedir.

Mekan cinsiyetlendirmesi ile birlikte öznelikleri sorgulanan kadın karakterlerin özne olamama halleri Türk Sineması'nda sık görülen bir olgudur. $\mathrm{Bu}$ nedenle özne(s)neleştirilmişs karakterler yaratan yönetmenler görülebilmektedir. Özne olmaya çalışan ancak, toplumsal düzenin kodları aracılığıyla özneliğine kavuşamayan kadın karakterler nesne olmaya mecbur bırakılmışlardır. İddiam; özne olamadığı gibi, nesne olarak kalmış, ancak kadınlığına dair öyküleriyle anlatı merkezine alınan kadın karakterlerin dahi Türk Sineması'nda birçok filmde özne(s)neleştirilmişs kadın karakterleri yarattığıdır. İddia ettiğim kavram üzerinden geliştirilmesi gereken sinematografik çözüm stratejilerinden biri, özneliği ortaya koyulan, benlikleriyle deneyimleri gerçeklikten kopmadan sunulan ve radikal sinematik dille kadının kamusal alanlarda da varolabileceği filmler üretilmesidir. $\mathrm{Bu}$ bağlamda, kadın yönetmenlerin de sayıca Türk Sineması'nda az oluşu ve sinema sektöründe varolamayış problemleri üzerinde tartışılması gereken başka bir konu ortaya çıkmaktadır. Dr. Reena Bhavnani Barriers to Diversity in Film adlı raporunda dünya sinemasında kadın yönetmenlerin konuma dair yaptığı çalışmada durumu özetlemektedir: 'Kadın yönetmenlerin, yapımcıların ve senaryo yazarlarının eksikliği beyazperdede farklı kadın portrelerinin ortaya çıkmasına yol açıyor. Bu da kadinlar adina daha az rol modeli demek (IES 2006). Filmler kadin perspektifinden yoksun kalabilir; tıpkı daha az etnik azınlı̆̆n ya da yetersiz kadronun böyle özel perspektiflerin eksikliğine neden olabileceği gibi. Ĕger yetersiz temsil edilenlerin bakış açıları beyazperdede gösterilmezse onlar sinema alanında çalı̧̧ma isteği duymazlar (IES 2006)." (Kelly, Robson 2014: 312). Kadın yönetmenler sinema sektöründe erkek yönetmenlere göre sayıca daha az oldukları için bakış açılarında varolan kadınsı farklılık da izleyiciye ulaşmakta problem yaşamaktadır. Bu nedenle, 
kadın yönetmenlerin varlığının çoğalmasıyla kadın karakterlerin anlatıdaki temsil ediliş şekilleri artacak ve erkek bakışına hizmet eden sinematik kodlar kadına ait bakış açısıyla yapıbozuma uğratılabilecektir. Biyoloji kaderimiz olmamalıdır!

\section{KAYNAKÇA}

AKBULUT, Hasan (2008), Kadına Melodram Yakışır: Türk Melodram Sinemasında Kadın Imgesi, Bağlam Yayınları, İstanbul.

ARENDT, Hannah (2011), İnsanlık Durumu, İletişim Yayınları, İstanbul.

BAL, Mieke (1999), Narratology Introduction to the Theory of Narrative, University of Toronto Press, Toronto.

COLOMINA, Beatriz (2011,) Mahremiyet ve Kamusallık, Çev. Aziz Ufuk Kılıç, Metis Yayınları, İstanbul.

COŞKUN, Çiçek (2015), '’1990 Sonrası Türk Sineması ve Derviş Zaim', 10

Kasim 2015, https://sadibey.com/2008/02/29/1990-sonrasi-turk-sinemasi-vedervis-zaimdocumentarygenres/\#.Vs7SQfmLTIU.

DEMIRHAN, Metin, Giovanni, Scognamillo (2002), Erotik Türk Sinemast,

Kabalcı Kitabevi, İstanbul.

DUYAN, Yektanurşin (2013), “'1980 Öncesi Türkiye Sinemasında Kadın

Temsilleri: Adı Vasfiye Filmi Üzerine Bir İnceleme’,, 2. International Conference on Communication, Media, Technology and Design North Cyprus, 09 A ğustos 2013, http://www.cmdconf.net/2013/makale/PDF/69.pdf. ESEN, Kuyucak, Şükran (2000), 80’ler Türkiyesi'nde Sinema, Beta Yayınları, İstanbul.

FRASER, Nancy (1990), ''Rethinking the Public Sphere: A contribution to the Critique of Actually Existing Democracy”, Social Text, Sayı:25/26, s. 5680.

HABERMAS, Jurgen (2013), Kamusallı̆̆ın Yapısal Dönüşümü, Çev. Tanıl Bora, İletişim Yayınları, İstanbul.

ILLICH, Ivan (1996), Gender, Çev. Ahmet Fethi, Ayraç Yayınevi, Ankara. JOHNSTON, Claire (2008), 'Karşı Sinema Olarak Kadınların Sineması', Sinema İdeoloji Politika: Büyüleyen Faşizm ve Diğer Yazılar, Der. Burak Bakır, Yörükhan Ünal, Sali Saliji, Nirengi Yazılar, Ankara, s. 281-293. 
KELLY, Gabrielle, Cherly Robson (2014), Dünya Kadın Sinema

Yönetmenleri, Çev. Nazlı Pakkan, Agora Kitaplı̆̆ı̆, İstanbul.

NELMES, Jill (2015), 'Sinemada Cinsiyet ve Cinselliğin Sunumu', Çev.

Ertan Y1lmaz, 09 Haziran 2015, http://www.kaosgl.com/sayfa.php?id=688.

O’CONNOR, Barbara (1984), 'Aspects of Representation of Women in Irish Film”, The Crane Bag Journal, Numara 2, Say1 8, s. 79-83.

SCOGNAMILLO, Giovanni (1990), Türk Sinema Tarihi: 1896-1986, Metis Yayınları, İstanbul.

SENNETT, Richard (2013), Kamusal Insanın Çöküşü, Çev. Serpil Durak, Abdullah Yıldız, Ayrıntı Yayınları, İstanbul.

SMELIK, Anneke (2008), Feminist Sinema ve Film Teorisi ve Ayna Çatladl, Çev. Deniz Koç, Agora Yayınları, İstanbul.

SOYKAN, Fetay (1993), Türk Sinemasında Kadın 1920-1990, Altındă̆ Matbaacılık, İzmir.

ULUSAY, Nejat (2008), Melez Imgeler: Sinema ve Ulusötesi Oluşumlar, Dost Kitabevi, Ankara.

WEINTRAUB, Jeff (1997), Public and Private in Thought and Practice

Perspectives on a Grand Dichotomy, Ed. Jeff Weintraub, Krishan Kumar, The University of Chicago Press, Chicago\& London. 